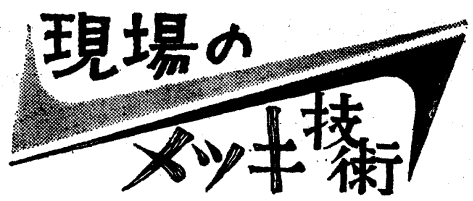

(11)(最終回)

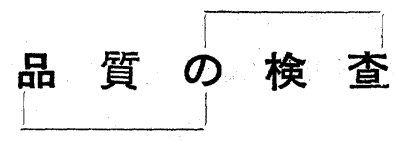

小西六写真 山之内昭 夫

定められたメッキの品質をるつ製品を作って行くために，現場 的にとり上げればならない問題がいくつかあるが，これらについ ては既に前回までにその概略を述べた。今回はでき上った製品の 検查の考え方を紹介して，この講座の結びとしょう。

\section{1. メッキの検査の意義}

メッキの品質特性については既に触れた が，(1958・11月号）目標とする品質特性住対 してできばえが合っているかぞうかを調べる 必要がある。これはメッキ作業にはどうして む“バラッキ”が避けられないからである。 実際には各品質の特性に対してつぎのような 検査が行なわれている。
(1) 厚み検査
(2) 有孔度 (ピソホール)
(3) 腐食試験
(4) 密着性
(5) 内部ヒズミの試験
(6) 耐摩耗性試験
（7）外観検查

さてメッキの場合には, メッキ加工ののち 部品がそのまま製品となる場合は比較的少な くてメッキ工程に次ぐ組立工程なぞを経て製 品として完成される場合が多いと思われる。 従ってこうした場合にはメッキ工程は機械加 工程と組立工程との中間工程といらことにな る。メッキ工程に対して行なわれる検査は， 次の工程に対して不良品を送らないことがそ の原則となることはもとよりで, その意味で 工程検査，または中間検査と呼ばれている。 目標の品質特性に合致しない部品がそのまま 次の工程に送られたために, 次の工程の作業 に支障を生じたり，不良部品が組み立てられ て製品全体がオシャカになるなどはよく経験
することである。

\section{2. 工程検査の方法}

工程検查の目的は直接には，でき上った部 品を良品と不良品とに選別することにある が，工程検査から得られるデータを利用して 不良の発生の予防に役立たせることが工程検 查をより効果あるすのにする。その主な方法 としてつぎのようなものがある。

(1) 管理図法

既に繰り返し述べたように，不良個数（ま たは不良率）の管理図, 平均值と範囲の管理 図を用い，常に打点が管理限界線の内にある ように, 工程を管理するのが管理図の用い方 である。

（2）初物検查

初物検查はメッキ作業を開始する前论, 数 個〜数十個の部品の加工を行ない，できれば 之を検査して良品であることを確認した上で 作業を開始する方法である。この方法は一見 繁雑の上5亿思われるけれぞも, メッキ作業 では一般に一回に多数の部品の加工が行なわ れるため, 工程のどこが異常があると不良 の損害が大きくなる恐れがある。従って特に メッキ不良が発生すると全体の不良の損害が 大きくなるような部品の場合には，初物検查 は有効であると云える。

(3) 巡回検查

一般にメッキの検査はメッキ作業ののち, 品物を乾燥してから行ならが, 検查員が直接 
製造工程へ出向いて検査を行なう場 合もあ る。これを巡回検査と呼んでいる。これはメ ッキ作業が進行している間に定期的にその時 までにでさた品物を検查して，む乙不良品が 多くでさいれば，品物を不合格とすると同 時に作業を中止させて処置をとり，不良品が 多量に出るのを未然に防ぐことができる。前 項の初物検査と巡回検査とをうまく組合わせ て, 合理的な工程検查をしている工場もあ る。しかし巡回検査は，検査が比較的簡単に 行なえる場合に薑している。余り暇取ってい ては工程検査としての意義が失われる。従っ て検查の方式も品物の全数を 1 個 1 個検査す る全数検查より，一群の品物から抜取った少 数の品物を検查する抜取検査の方が望まし Wo

\section{3. 全数検查と抜取検查}

全数検查 ( $100 \%$ 検査, 選別) とは, 検査 員に提出された製品を 1 個 1 個試験, または 測定し,その結果を規格と比較して,良品と不 良品とに分類して良品だけを合格とする検査 をいら。これに対して抜取検査とは検査員に 提出された一群の製品（これをロット〔lot〕 という) から抜取った少数の製品(これをサ ンプルという) を調べて，その結果をロット に対する判定の基準と比較して, 合格ロット 々不合格口ットに選別する检查をいら。

全数検查は良品と不良品の選別に誤りがな ければ理想的な検査法である。しかし実際に は選別に誤りがあることも見逃すことはでき ない。ともすると，全数検査は完全である， つまり, 品物のすべての品質特性を検查し, しかも選別の䛊りは絶無であるというように 受取られがちであるが, 限られた人員の検査 員で, 多量の検查個数を処理するとすると, 1 個当りの検査時間を短縮するか，あるいは 検査の項目を減らさねばならない。この結 果, 全数検査は完全である, という状態から かなり隔りを生ずることとなる。このよ5な
場合，抜取検査を用いると，検査する必要の ある項目を数多く検查することができ，また は 1 個当りの検査時間に余裕ができるので， 検査をていねいに行な学る。しかし不良品が 1 個でも合格となって次の工程へ送られて も, その不良品によって大きな損害を招くよ うな場合にはどうしても全数検査を適用せ ねばならない。また前に述べた検査法の5 ち, 外観検査を除く各検查はいわゆる破壊検 查（検査をすることによって品物がオシャカ となる)であって，これらの場合には必ず抜 取検査でなければならない。な和，外観検査 の場合にも合理的な抜取検查の実施が可能で ある。

\section{4. 拔取検查の教え方}

抜取検査を行なって不合格ロットについて だけ選別検查を行なうやり方と，抜取検査を 行なわず最初から全数検査を行なったときの 違いを図示すると第1図のようになる。
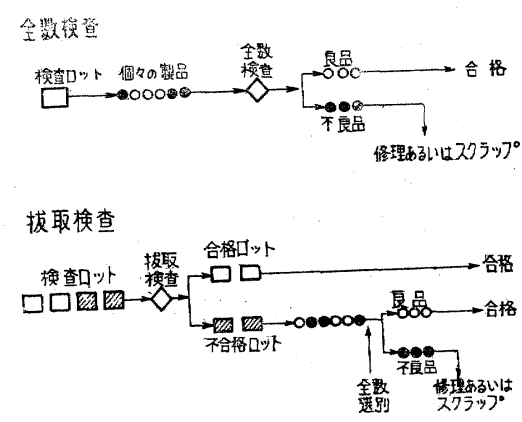

第 1 図

もとより拔取検査でほとんぞのロットが不 合格になるよらであれば，最初から全数検査 をやった方ががって検查の手間が省ける。 しかし作業の標準化が進み工程が安定化する に従って, 不合格ロットが時たましか出ず, すなわら大部分のロットが拔取検査で合格と なるはずであるしこのことが工程が安定か 否かの一つの目安となるわけである。 
つぎに実際の抜取検査の一例を示して見よ

5。2,000個のロットの品物にメッキを行な い,そのロットから150 個のサンプルをラン ダムにデタラメに抜取って検査し, その中に 見出した不良品の数が 2 個までなら, その口 ットを合格とし，3個以上ならそのロットを 不合格とする。この場合の検查の手順を図示 すると第2図のようになる。

\begin{tabular}{c|c|c}
$\begin{array}{c}\text { 試料の大キサ } \\
(\mathrm{n})\end{array}$ & $\begin{array}{c}\text { 合格判定個数 } \\
\text { (Ac) }\end{array}$ & $\begin{array}{c}\text { 不合格判定個数 } \\
(\mathrm{Re})\end{array}$ \\
\hline 150 & 2 & 3 \\
\hline
\end{tabular}

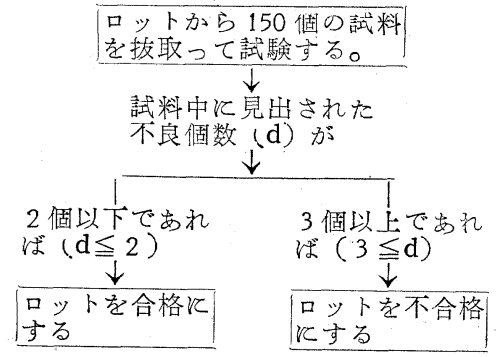

第 2 図
ロットの大きさに対して，試料の大きさ， 合格判定個数执よび不合格判定個数をどのよ 万に決めるかは, 各䡛品, 各部品により全く 異なるがこれらの詳細についてはこの稿で は省略することとする。必要なことは定めら れた抜取方式に対して，いいもットが抜取 合格となるレベルまで到達することにある。

一むすび-

この稿を最後として「現場のメッキ技術」 の講座を終ることとなった。一年にわたっ て，いろいろの間題をつついたわけである が，すべて“りゅうとらだび(竜頭蛇尾)”に 終ってしまった。しかし筆者が現場人の一員 として考光て来た根底のものは，メッキ不良 というものは必ずある限度以下に減らすこと がでさるということである。そのためには現 場のどのような間題に着眼し，しかもそれぞ れの問題に対していかに処すべきかというこ とであった。この考え方が僅かなりとも読者 諸兄に伝わり，この講座の一行でも参考にな ったとするならば筆者の望外の喜びである。

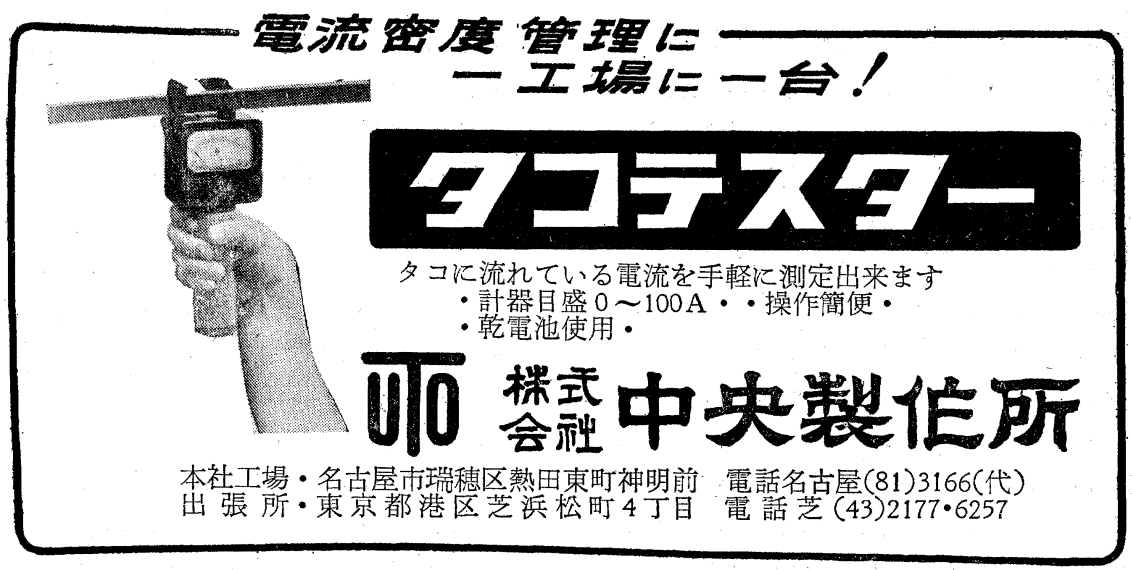

